\title{
Predicting the Compressive Strength of Rubberized Concrete Using Artificial Intelligence Methods
}

\author{
Amedeo Gregori ${ }^{1}$, Chiara Castoro ${ }^{1, *(1)}$ and Giri Venkiteela ${ }^{2}$ \\ 1 Department of Civil, Building and Environmental Engineering, University of L'Aquila, Via G. Gronchi 18, \\ 67100 L'Aquila, Italy; amedeo.gregori@univaq.it \\ 2 New Jersey Department of Transportation, 1035 Parkway Avenue, P.O. Box 600, Trenton, NJ 08625-0600, USA; \\ giri.venkiteela@dot.nj.gov \\ * Correspondence: chiara.castoro@graduate.univaq.it
}

Citation: Gregori, A.; Castoro, C.; Venkiteela, G. Predicting the

Compressive Strength of Rubberized Concrete Using Artificial Intelligence Methods. Sustainability 2021, 13, 7729 https://doi.org/10.3390/su13147729

Academic Editors: Raf Dewil,

Rawaz Kurda and Hawreen

Hasan Ahmed

Received: 3 June 2021

Accepted: 7 July 2021

Published: 11 July 2021

Publisher's Note: MDPI stays neutral with regard to jurisdictional claims in published maps and institutional affiliations.

Copyright: (C) 2021 by the authors Licensee MDPI, Basel, Switzerland. This article is an open access article distributed under the terms and conditions of the Creative Commons Attribution (CC BY) license (https:/ / creativecommons.org/licenses/by/ $4.0 /)$.

\begin{abstract}
In this study, support vector machine (SVM) and Gaussian process regression (GPR) models were employed to analyse different rubbercrete compressive strength data collected from the literature. The compressive strength data at 28 days ranged from 4 to $65 \mathrm{MPa}$ in reference to rubbercrete mixtures, where the fine aggregates (sand fraction) were substituted with rubber aggregates in a range from $0 \%$ to $100 \%$ of the volume. It was observed that the GPR model yielded good results compared to the SVM model in rubbercrete strength prediction. Two strength reduction factor (SRF) equations were developed based on the GPR model results. These SRF equations can be used to estimate the compressive strength reduction in rubbercrete mixtures; the equations are provided. A sensitivity analysis was also performed to evaluate the influence of the $\mathrm{w} / \mathrm{c}$ ratio on the compressive strength of the rubbercrete mixtures.
\end{abstract}

Keywords: rubbercrete; strength reduction factor (SRF); artificial intelligence methods; Gaussian process regression (GPR); support vector machine (SVM)

\section{Introduction}

Waste tyre disposal represents a growing environmental problem, not to be overlooked. Globally, more than 500 million units of waste tyres are discarded every year without any treatment [1] and their increasing number has raised concerns worldwide due to the threat they pose directly and indirectly to human health and the environment. For this reason, recycling of waste tyres has been implemented in many countries.

The possibility of recycling scrap tyres as aggregates in concrete gained acceptance worldwide in the engineering sector, and positive results have already been achieved, preserving natural resources and helping to maintain ecological balance.

Scrap tyres undergo several processes to separate the steel wires from the rubber and to reduce the rubber to smaller crumbs. This crumb rubber can then be added into concrete mixture as partial replacement of the natural aggregates [2], modifying the concrete properties [3-11].

In some cases, cleaned, shredded rubber can be used. For example, the textile components are removed, steel fibres are pulled out, and the rubber surface is sometimes subjected to pre-treatments to consolidate the adhesion with the cement paste, improving the final properties of the modified concrete. The size, shape, and level of cleanliness of the fragments of rubber are essential factors in defining the final characteristics of the material.

The resulting material is called rubbercrete, a lightweight concrete with specific mechanical, thermal, acoustic, and rheological characteristics. Rubbercrete exhibits numerous benefits compared to conventional concrete, such as lower density [12], increased ductility [13], enhanced plastic capacity [14], higher toughness [15], higher impact resistance [16], better resistance to chloride penetration [17], lower thermal conductivity [2], higher noise reduction [18], and better electrical resistivity [19]. 
Rubbercrete is also known to have better energy dissipation, durability, and damping ratios compared to normal concrete $[20,21]$. Such features enable rubbercrete to be used in impact resistance structures, such as road bumpers and sound barriers [22]. Despite such advantages, a reduction in the compressive strength is observed throughout the literature. This reduction in strength is caused by the weak bond between the cement matrix and the crumb rubber due to the hydrophobic properties of rubber [23]. Rubber repels water and traps air, causing the formation of micro air pockets between the rubber and the cement, which thicken the interfacial transition zone [13]. This weak chain within concrete leads to micro-cracks due to stress concentration and induces structural failure [18]. Furthermore, aggregate properties have a strong effect on concrete compressive strength [24]; when aggregates of higher density and strength are replaced with less dense rubber aggregates, the compressive strength decreases.

In different studies, authors noticed that the size, proportion in concrete, and different surface textures of the rubber particles have a significant effect on concrete strength properties. Generally, the reduction in compressive strength is observed to be larger when coarse aggregates are replaced with crumb rubber compared to fine aggregates [6,12,13,25-27]. Concrete containing coarse rubber aggregates exhibits a reduction in strength but also significant energy absorption [28].

It was found that replacing less than $5 \%$ in volume of the natural aggregates with waste tyre rubber does not induce any particular change in the performance of the material [5].

Compared to bending and tensile strength, compressive strength decreases more [3,29-31].

To enhance the compressive strength of rubbercrete, the adhesion between the rubber particles and the cement matrix can be increased by operating natural or chemical pretreatments on the rubber particles [3,5,8,13,18,30,31]. Certain studies [18,29] reported that rubber particles washed in water exhibited a $16 \%$ increase in compressive strength compared to untreated rubber, and a further improvement (higher than 57\%) when rubber particles were treated with carbon tetrachloride.

Although this material has been used for a wide variety of construction applications, clear design guidelines for rubbercrete mixtures have not been developed. Especially for structural applications, in which the use of rubber particles is allowed as replacement of fine aggregates in small percentages (up to a maximum of $10 \%$ ), and only under severe quality control processes [32,33], specific studies are required to better understand the phenomenon of strength reduction compared to the obvious reduction that occurs when coarse aggregates are replaced.

The main purpose of this study is to develop a simple model that can predict the compressive strength reduction of concrete containing crumb rubber as a partial replacement for fine aggregates (sand fraction). For this purpose, advanced modelling techniques were employed on various rubbercrete compressive strength data gathered from the literature; experimental campaigns and predictive equations of the strength reduction factor (SRF) are provided.

\section{Methodology of the Study}

In this study, the reduction in compressive strength in rubbercrete mixtures is investigated, concerning the following mix design parameters: percentage of rubber, size of crumb rubber, cement content, water content, additions, pre-treatments on crumb rubber, fine aggregate content, and coarse aggregate content.

In Appendix A, experimental data from different literature studies concerning rubbercrete mixtures, where natural fine aggregates (sand fraction) were substituted with rubber of the same size [28,32,34-42], are reported.

For each mixture considered, the mix design parameters are indicated, and the respective compressive strength values are reported in relation to the amount of aggregates substituted. The percentages of substitution refer to the type of aggregate considered (fine).

To better understand the global trend, the compressive strength values are reported in the form of the strength reduction factor (SRF) and are plotted in Figure 1, where the 
percentages of rubber reference the total volume of aggregates in the mixture. The strength reduction factor is defined as the ratio between the compressive strength of the concrete with a certain percentage of rubber and the compressive strength of the concrete without rubber: $S R F=f_{c} / f_{c 0}$.

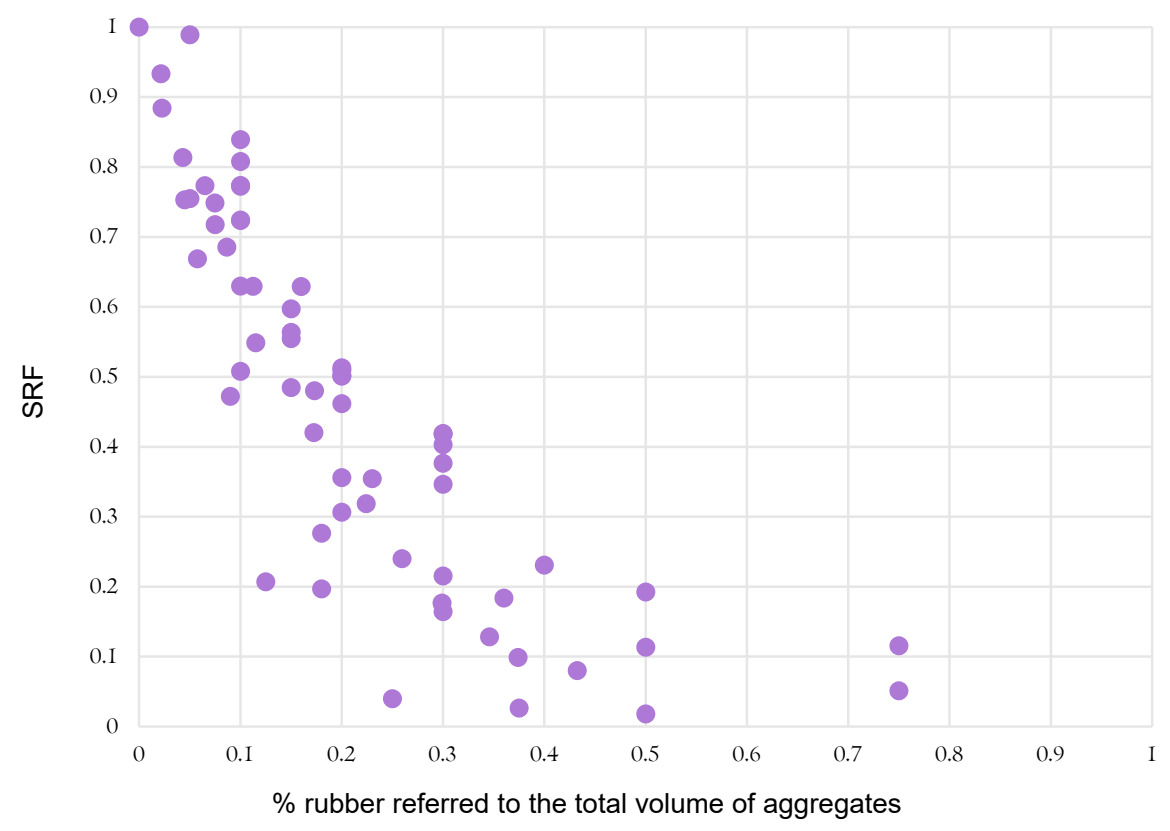

Figure 1. Experimental data from the literature (Appendix A). Strength reduction factor (SRF) values are reported with reference to the percentage (in volume) of the natural fine aggregates substituted with rubber.

The values in Figure 1 show a decrease in the compressive strength. This reduction is higher when the amount of rubber particles replacing the natural sand increases.

An accurate study of the mix design procedures is useful to better understand the rubbercrete behaviour under load and to set conditions for the starting concrete mix design to obtain the required performance from the rubbercrete.

\section{Artificial Intelligence Modelling Techniques}

In this study, two different artificial intelligence (AI) models were employed to conduct a sensitivity analysis and to create a uniform platform for analysis of the collected literature data (provided in Appendix A). The AI models used were support vector machine (SVM) and Gaussian process regression (GPR). The rubbercrete strength models were developed using MATLAB software and their performances were compared using test data. The best-performing model was used for the evaluation of the influence factors in rubbercrete strength prediction.

SVMs are based on the structural risk minimization principle [43], which can find a hypothesis with the lowest true error. This learning method performs non-linear classification, regression, and outlier detection with an intuitive model that can be approximately represented by Figure 2, which is adapted from Meyer's work [44]. Figure 2 shows the optimal separating hyperplane between two classes, which is obtained by maximizing the margin between the classes' closest points. The points lying on the boundaries are called support vectors and the middle of the margin is the optimal separating hyperplane [44]. SVM is the statistical learning theory that can rather precisely identify the factors that must be taken into account to learn successfully [45]. 


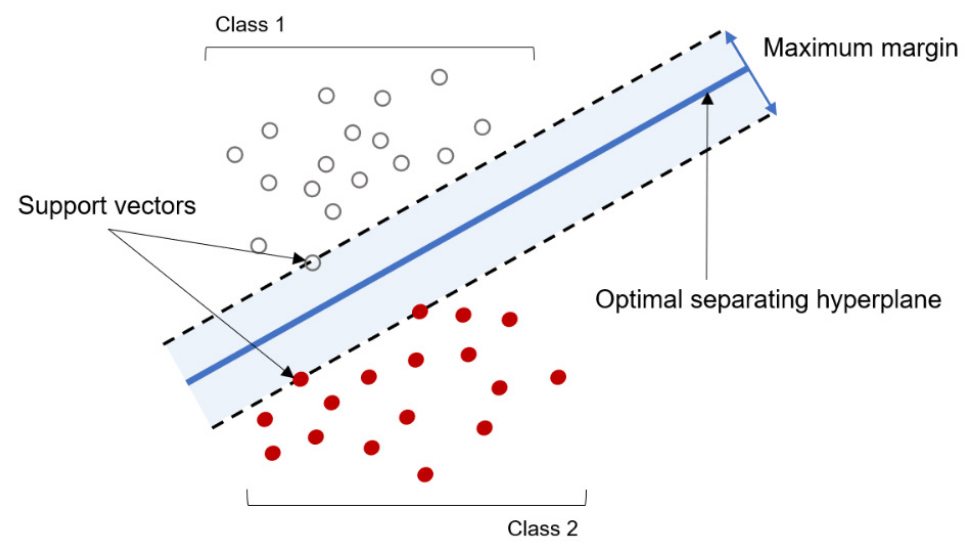

Figure 2. Linear classification using support vector machine (SVM).

GPRs capture a wide variety of relations between inputs and outputs by utilizing a theoretically infinite number of parameters and letting the data determine the level of complexity through the means of Bayesian inference [46,47]. GPR models are nonparametric kernel-based probabilistic models. Consider the training set $\left\{\left(x_{i}, y_{i}\right) ; i=1,2, \ldots, n\right\}$, where $x_{i} \in \mathbb{R}^{d}$ and $y_{i} \in \mathbb{R}$, drawn from an unknown distribution. A GPR model addresses the question of predicting the value of a response variable $y_{\text {new }}$ given the new input vector $x_{\text {new }}$ and the training data. A linear regression model is in the form $y=x^{T} \beta+\varepsilon$, where $\varepsilon \sim N\left(0, \sigma^{2}\right)$. The error variance $\sigma^{2}$ and the coefficients $\beta$ are estimated from the data. A GPR model explains the response by introducing latent variables $f\left(x_{i}\right), i=1,2, \ldots, n$, from a Gaussian process (GP) and explicit basis functions $h$. The covariance function of the latent variables captures the smoothness of the response, and basic functions project the inputs $x$ into a $p$-dimensional feature space [48].

In this study, 89 different mixtures were used as a test set. The training data were developed based on experimental data in the literature, as shown in Appendix A. The input parameters included cement content $\left(\mathrm{v}_{1}\right)$, fine aggregate content $\left(\mathrm{v}_{2}\right)$, coarse aggregate content $\left(\mathrm{v}_{3}\right)$, aggregate pre-treatment condition $\left(\mathrm{v}_{4}\right)$ ( 1 for soaked and 0 for non-soaked), water-tocement ratio $\left(\mathrm{v}_{5}\right)$, fine aggregate replacement percentage $\left(\mathrm{v}_{6}\right)$, and coarse aggregate replacement percentage $\left(\mathrm{v}_{7}\right)$. The corresponding output was set as the compressive strength of the concrete.

Based on artificial intelligence models literature and our experience, a typical data division between testing and training data is identified in a range of $10-20 \%$ for testing and $90-80 \%$ for training. In this study, the developed SVM and GRP models' performances were evaluated using 15 testing data (about 17\%) and 74 training data (about 83\%). Figure 3 shows the models' performance based on original compressive strength values. A comparison of these two models, based on the strength reduction factor (SRF), was performed; this is discussed in the next section.

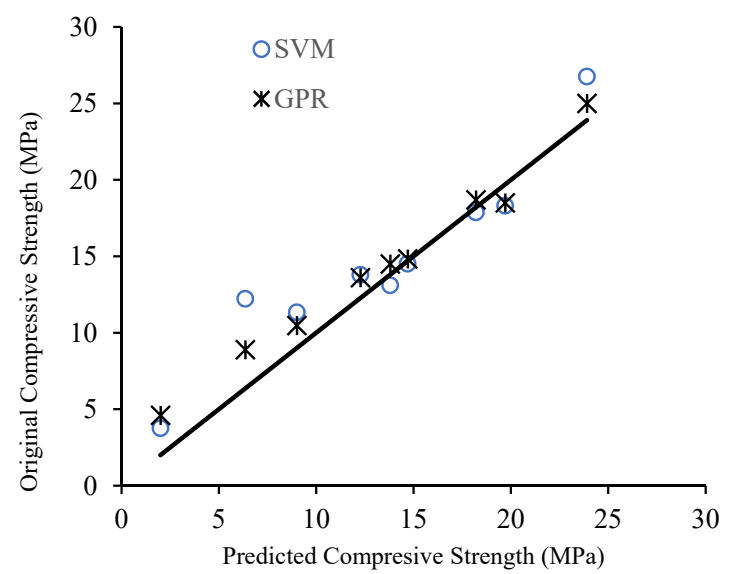

Figure 3. Models' performance based on testing data. 


\section{Results and Discussion}

\subsection{Comparing GPR and SVM Model Performance}

To test the performance of GPR and SVM models, simulations of mix design procedures were carried out, starting from a reference mixture with cement $400 \mathrm{~kg} / \mathrm{m}^{3}$, sand $800 \mathrm{~kg} / \mathrm{m}^{3}$, and gravel $1100 \mathrm{~kg} / \mathrm{m}^{3}$. While keeping these three parameters constant, the $\mathrm{w} / \mathrm{c}$ ratio was considered, ranging from 0.25 to 0.65 , in both treated and non-treated rubber particles (treated rubber particles were soaked in water before their use in the mixture). Substitutions of sand aggregates were then operated with percentages of rubber ranging from $0 \%$ to $100 \%$, as summarised in Table 1 .

Table 1. Mix design proportions for GPR and SVM models' predictions.

\begin{tabular}{|c|c|c|c|c|c|c|}
\hline $\begin{array}{c}v_{1} \\
\text { Cement } \\
\text { Content } \\
\mathrm{kg} / \mathrm{m}^{3}\end{array}$ & $\begin{array}{c}v_{2} \\
\text { Fine } \\
\text { Aggregate } \\
\text { Content } \\
\mathrm{kg} / \mathrm{m}^{3}\end{array}$ & $\begin{array}{c}v_{3} \\
\text { Coarse } \\
\text { Aggregate } \\
\text { Content } \\
\mathrm{kg} / \mathrm{m}^{3}\end{array}$ & $\begin{array}{c}\mathrm{v}_{4} \\
\text { Aggregate } \\
\text { Pre-Treatment }\end{array}$ & $\begin{array}{c}\mathbf{v}_{5} \\
\text { Water/Cement } \\
\text { Ratio }\end{array}$ & $\begin{array}{c}\mathbf{v}_{6} \\
\text { Replacement } \\
\text { of Fine } \\
\text { Aggregate } \\
\%\end{array}$ & $\begin{array}{c}\mathbf{v}_{7} \\
\text { Replacement } \\
\text { of Coarse } \\
\text { Aggregate } \\
\%\end{array}$ \\
\hline 400 & 800 & 1100 & 1 or 0 & $0.25-0.65$ & $0-100$ & 0 \\
\hline
\end{tabular}

Hence, 98 mixtures were generated, and data were analysed with GPR and SVM models to predict the compressive strength and respective SRF values. The results are graphed in Figures 4-7, where the two models (GPR and SVM) are distinguished, and the rubber pre-treatments operated (soaked and non-soaked).

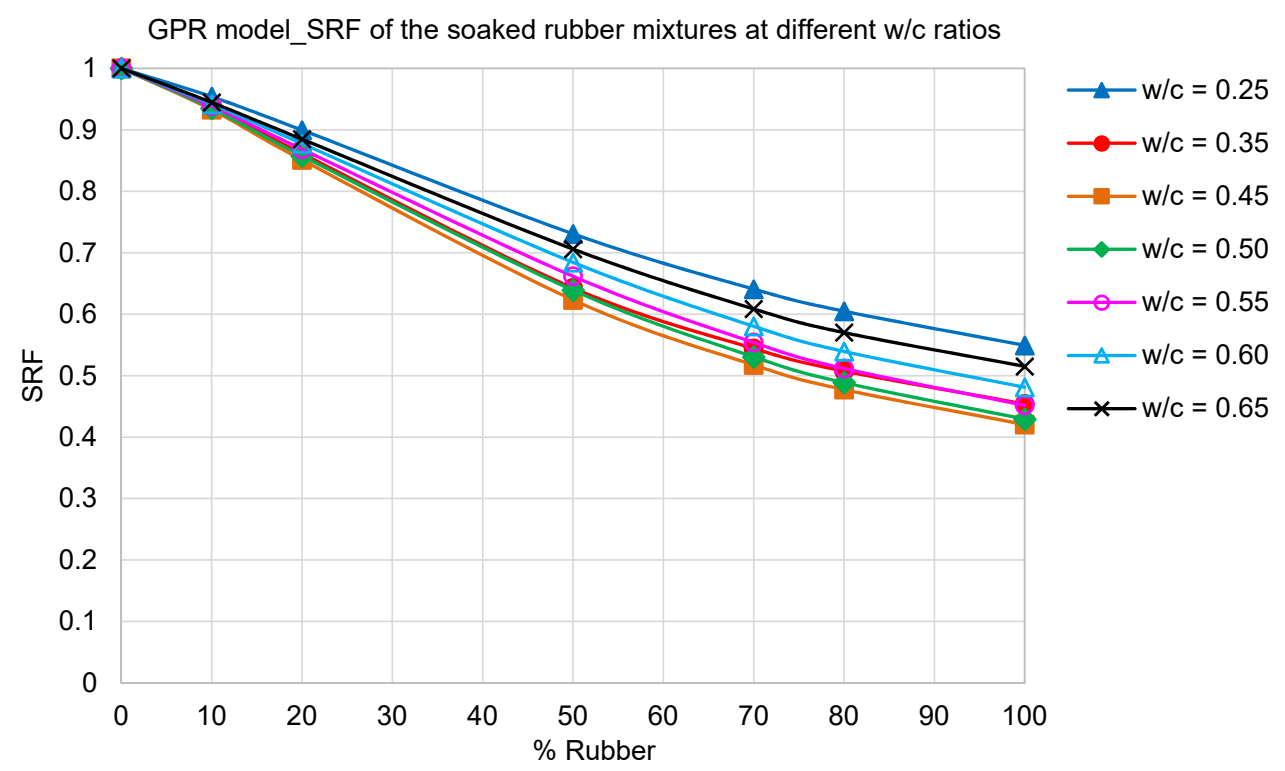

Figure 4. SRF values of different rubbercrete mixtures predicted with the GPR model at different $\mathrm{w} / \mathrm{c}$ ratios and soaked rubber particles.

Comparing Figures 5 and 7 with the trends in the experimental data from the literature in Figure 1, we observed that, in this study, the SVM model predictions were not representative of the compressive strength behaviour in rubbercrete mixtures. Experimental data in the literature state a reduction in the compressive strength when the rubber content increases (Figure 1). In Figure 5, the SRF values, which correspond to substitutions greater than a $50 \%$, increase instead of decreasing further. This is not physically significant because when the amount of rubber particles in the mixture increases, the compressive strength must decrease [27,49-52].

For non-soaked rubber mixtures (Figure 7), a greater reduction in compressive strength is expected compared to soaked rubber mixtures. No negative values of the SRF are physically admitted, as the greatest reduction that can be obtained is reporting a zero 
value for the compressive strength, not a negative value. In this case, the SVM model is not representative of the rubbercrete mixture's behaviour under compressive strength for this reason.

SVM model_SRF of the soaked rubber mixtures at different w/c ratios

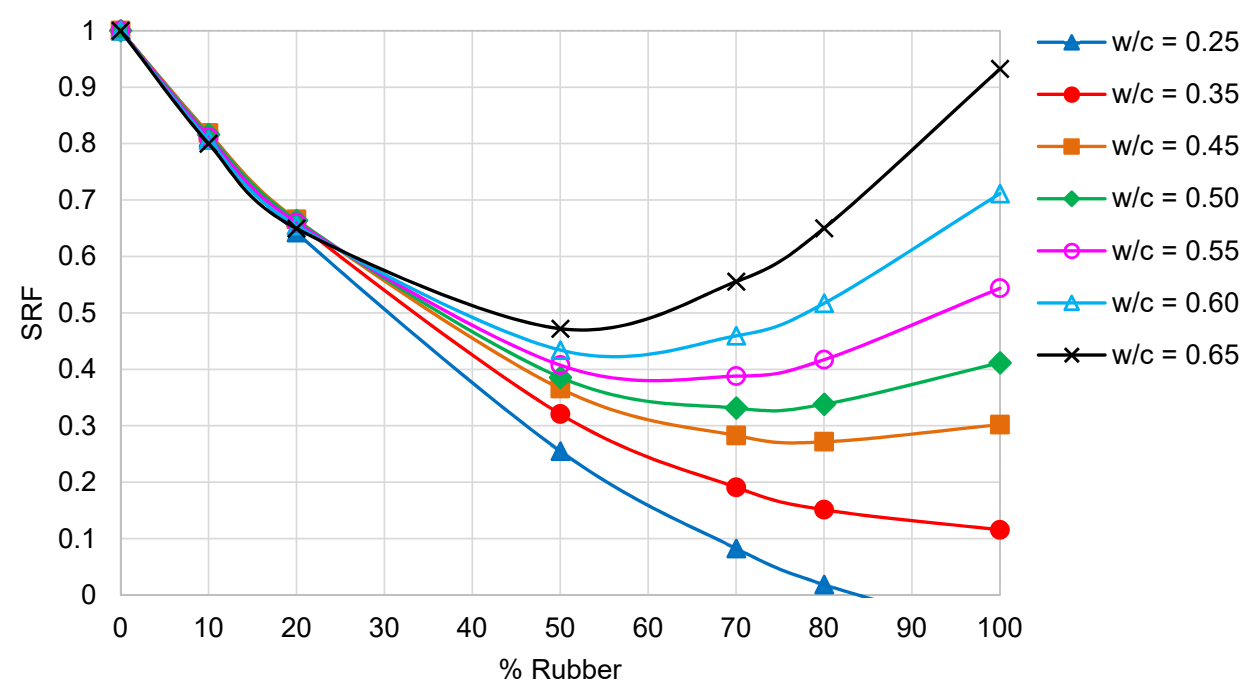

Figure 5. SRF values of different rubbercrete mixtures predicted with the SVM model at different $\mathrm{w} / \mathrm{c}$ ratios and soaked rubber particles.

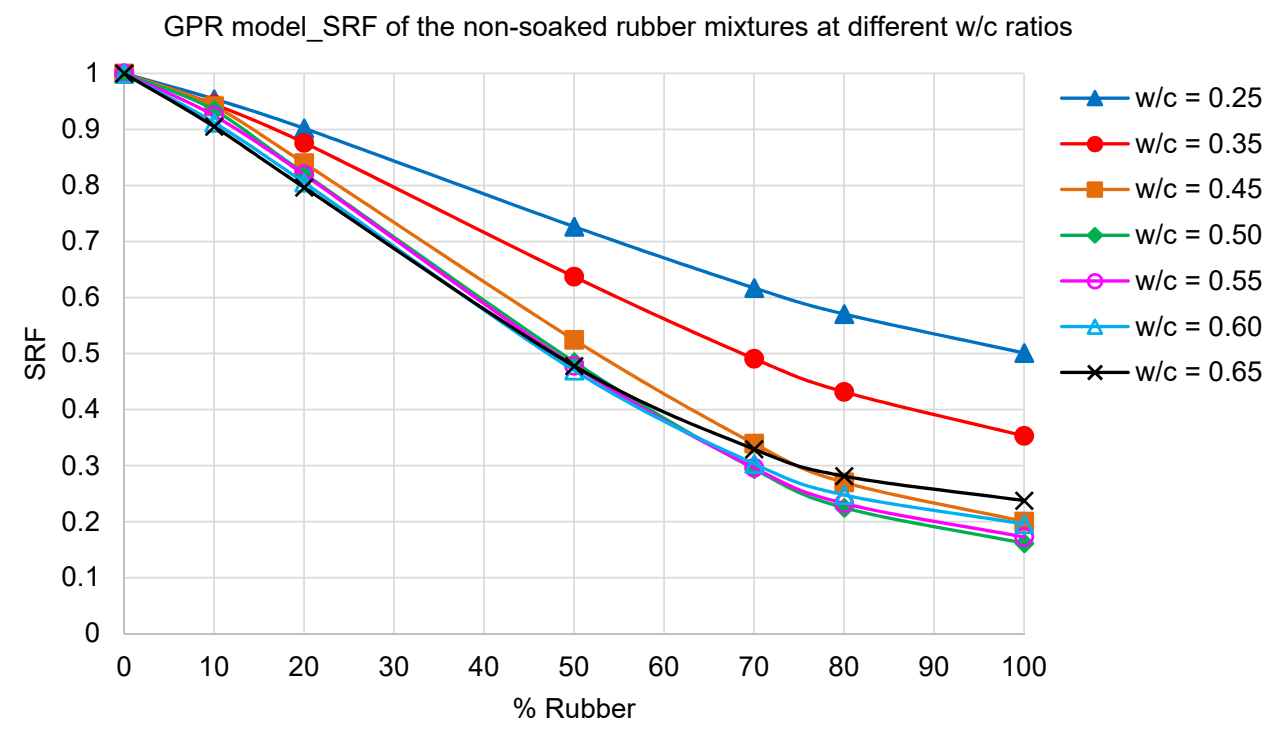

Figure 6. SRF values of different rubbercrete mixtures predicted with the GPR model at different $\mathrm{w} / \mathrm{c}$ ratios and non-soaked rubber particles.

The GPR model, instead, well-represented the behaviour of these rubbercrete mixtures, both for the soaked rubber mixtures and the non-soaked rubber mixtures. Following previous studies $[35,38,40]$, rubber particles that were pre-treated (soaked in water) presented a lower reduction in the compressive strength (Figure 4) compared to the rubber particles without pre-treatments (Figure 6). This was demonstrated for each $\mathrm{w} / \mathrm{c}$ ratio considered. In this study, the percentage of rubber, the $\mathrm{w} / \mathrm{c}$ ratio, and the condition of rubber (soaked or non-soaked) were the most influential parameters in the models. Among these, we observed that the $\mathrm{w} / \mathrm{c}$ ratio was the predominant factor influencing the model performance, so, for this reason, it was deeply investigative, as described in Section 3.2. 


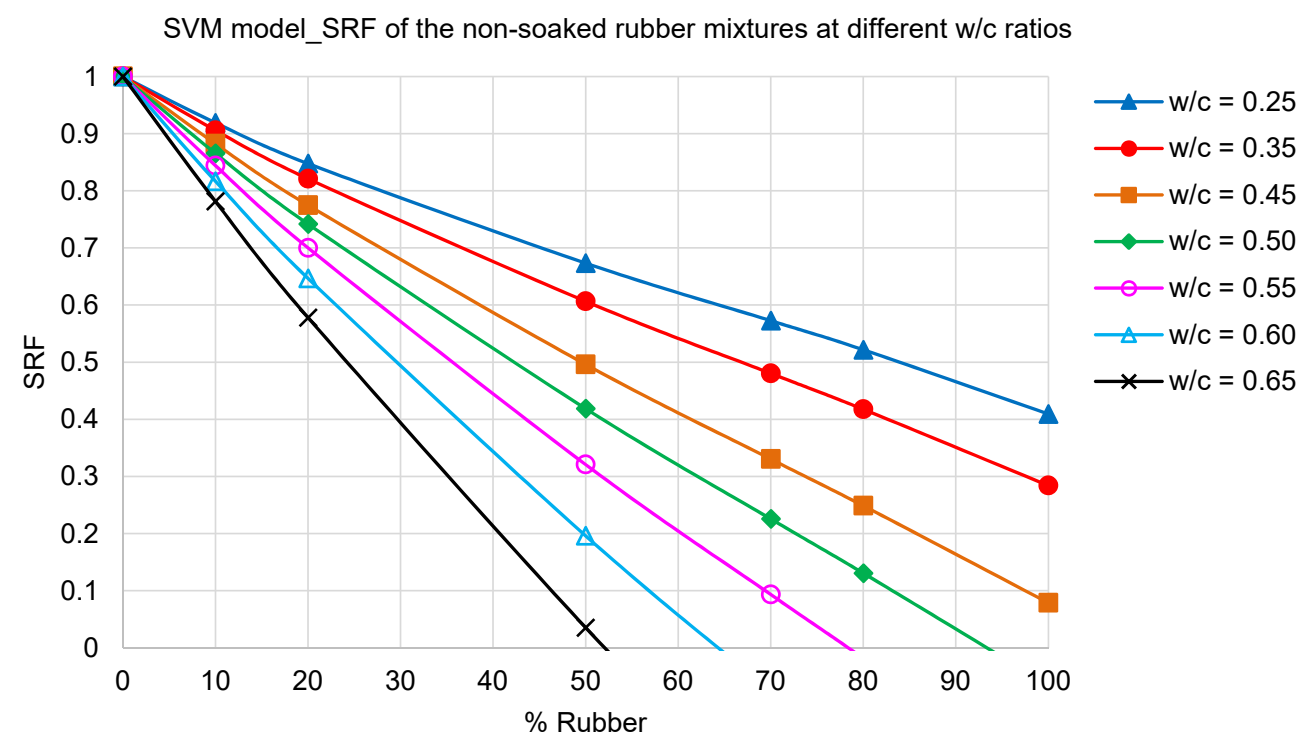

Figure 7. SRF values of different rubbercrete mixtures predicted with the SVM model at different $\mathrm{w} / \mathrm{c}$ ratios and non-soaked rubber particles.

\subsection{Influence of w/c Ratio on the Compressive Strength: Calibration Laws}

As graphed in Figures 4 and 6, different values of the SRF were obtained, varying the $\mathrm{w} / \mathrm{c}$ ratio in the range of $0.25-0.65$. Regressions were operated to fit the SRF values obtained at different percentages of substitution for each $\mathrm{w} / \mathrm{c}$ ratio considered, both in the case of soaked and non-soaked rubber particles. The equation of the regression curves is expressed in the exponential and polynomial form:

$$
S R F=\exp ^{-k x}
$$

where $x$ represents the amount of rubber in volume expressed in $\%$, and $k$ is the parameter depending on the $\mathrm{w} / \mathrm{c}$ ratio.

$$
S R F=a+b \bullet(1-x)^{m}
$$

where $x$ represents the amount of rubber in volume; $a, b$, and $m$ are the parameters depending on the $\mathrm{w} / \mathrm{c}$ ratio; and $a+b=1$.

For each $\mathrm{w} / \mathrm{c}$ ratio considered, the parameter $k$ and the parameters $a, b$, and $m$, together with the respective $R^{2}$ coefficients, were summarised and are reported in Table 2.

Table 2. Parameters of Equations (1) and (2) obtained for the GPR model, with soaked and non-soaked rubber particles included in the mixture.

\begin{tabular}{cccccccc}
\hline Pre-Treatment & $\mathbf{w} / \mathbf{c}$ & $\mathbf{a}$ & $\mathbf{b}$ & $\mathbf{m}$ & $\mathbf{R}^{\mathbf{2}}$ & $\mathbf{k}$ & $\mathbf{R}^{\mathbf{2}}$ \\
\hline \multirow{5}{*}{ Soaked } & 0.25 & 0.546 & 0.454 & 1.261 & 0.965 & 0.006 & 0.997 \\
& 0.35 & 0.451 & 0.549 & 1.439 & 0.965 & 0.008 & 0.994 \\
& 0.45 & 0.418 & 0.582 & 1.435 & 0.969 & 0.009 & 0.995 \\
& 0.50 & 0.426 & 0.574 & 1.383 & 0.971 & 0.009 & 0.996 \\
& 0.55 & 0.477 & 0.523 & 1.311 & 0.971 & 0.008 & 0.997 \\
& 0.60 & 0.448 & 0.552 & 1.334 & 0.972 & 0.008 & 0.997 \\
& 0.65 & 0.512 & 0.488 & 1.310 & 0.976 & 0.007 & 0.997 \\
\hline \multirow{5}{*}{ Non-soaked } & 0.25 & 0.495 & 0.505 & 1.133 & 0.959 & 0.007 & 0.995 \\
& 0.35 & 0.342 & 0.658 & 1.163 & 0.943 & 0.010 & 0.989 \\
& 0.45 & 0.180 & 0.82 & 1.248 & 0.921 & 0.016 & 0.979 \\
& 0.50 & 0.139 & 0.861 & 1.304 & 0.923 & 0.018 & 0.978 \\
& 0.55 & 0.152 & 0.848 & 1.350 & 0.930 & 0.017 & 0.983 \\
& 0.60 & 0.178 & 0.822 & 1.450 & 0.944 & 0.017 & 0.987 \\
& 0.65 & 0.224 & 0.776 & 1.555 & 0.956 & 0.015 & 0.990 \\
\hline
\end{tabular}


As noticed from Table 2, both polynomial and exponential laws fit well with the SRF values obtained from the GPR model, both with an $\mathrm{R}^{2}$ value-approximating unit.

To better understand how the $\mathrm{w} / \mathrm{c}$ ratio influences the rubbercrete mechanical behaviour, procedures were adopted to calibrate the parameter $k$ and parameters $a, b$, and $m$. In the graph in Figure 8, the values of parameter $k$ are reported in relation to the corresponding $\mathrm{w} / \mathrm{c}$ ratio.

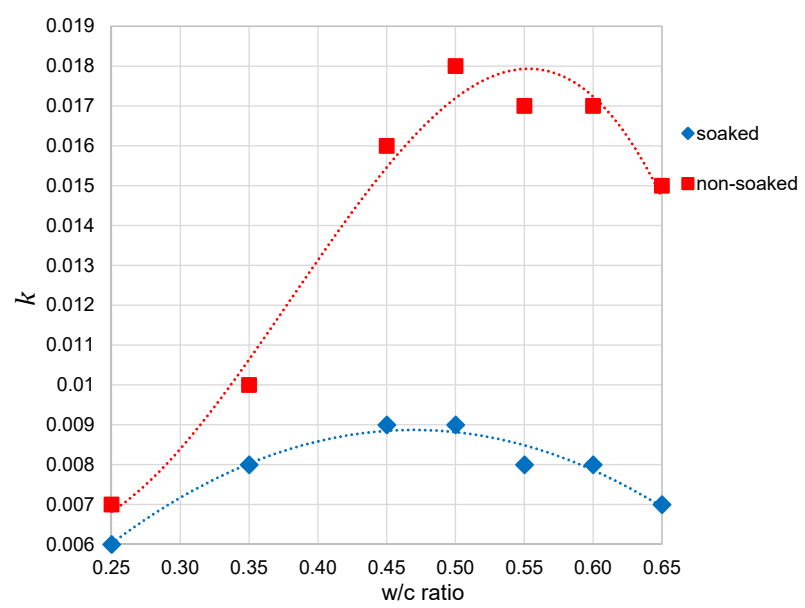

Figure 8. Calibration laws for the parameter $k$ with soaked and non-soaked rubber particles included in the mixture.

Regression analyses were conducted to obtain the equations of the parameter k:

- for soaked rubber particles in the mixture

$$
k=-0.0592 x^{2}+0.0556 x-0.0042
$$

- for non-soaked rubber particles in the mixture

$$
k=-0.5588 x^{3}+0.6368 x^{2}-0.1916 x+0.0237
$$

where $x$ represents the value of the $\mathrm{w} / \mathrm{c}$ ratio considered in the mixture.

For the mixtures with soaked rubber particles, it can be noted that for very low or very high $\mathrm{w} / \mathrm{c}$ ratio values, the decrease in the compressive strength is lower than for middle values of $0.45-0.50$. In contrast, for mixtures with non-soaked rubber particles, a general greater decrease in compressive strength was observed for $\mathrm{w} / \mathrm{c}$ ratio values higher than 0.45 .

For the parameters $a, b$, and $m$, a calibration procedure was also carried out, considering the cases of soaked and non-soaked rubber particles. The results are plotted in Figures 9 and 10. and $m$ :

Regression analyses were then operated to obtain the equations of the parameters $a, b$,

- for soaked rubber particles in the mixture

$$
\begin{gathered}
a=-3.4442 x^{3}+7.1842 x^{2}-4.3403 x+1.236 \\
b=3.4442 x^{3}-7.1842 x^{2}+4.3403 x-0.236 \\
m=22.351 x^{3}-33.572 x^{2}+15.883 x-0.9615
\end{gathered}
$$

- for non-soaked rubber particles in the mixture

$$
\begin{gathered}
a=4.4419 x^{2}-4.7362 x+1.4179 \\
b=-4.4419 x^{2}+4.7362 x-0.4179 \\
m=2.5408 x^{2}-1.2552 x+1.2902
\end{gathered}
$$


where $x$ represents the value of the $\mathrm{w} / \mathrm{c}$ ratio considered in the mixture.

Polynomial and exponential prediction laws for SRF values of rubbercrete mixtures with different $\mathrm{w} / \mathrm{c}$ ratios were obtained, both for soaked rubber particles and non-soaked rubber particles.

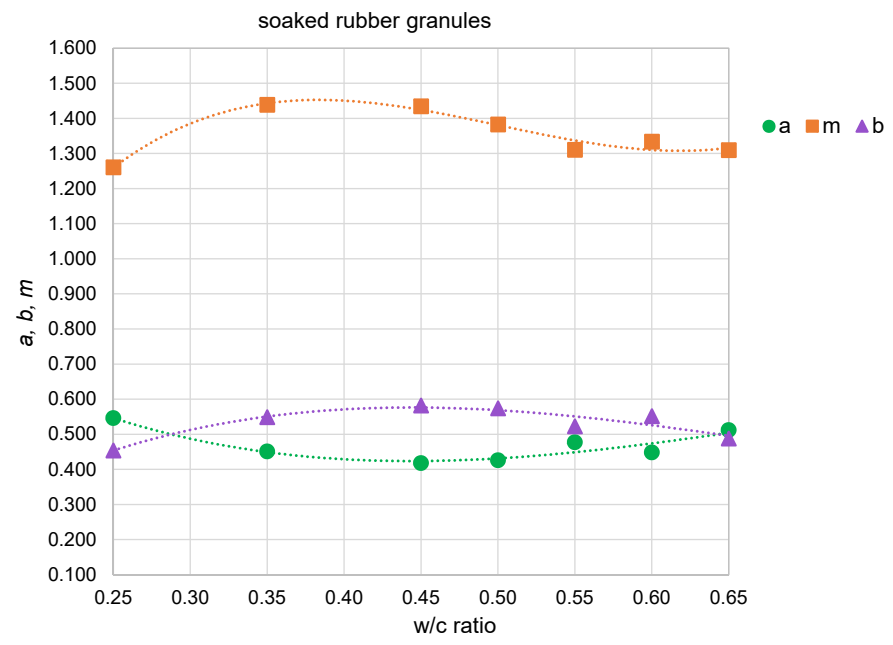

Figure 9. Calibration laws for the parameters $a, b$, and $m$, with soaked rubber particles included in the mixture.

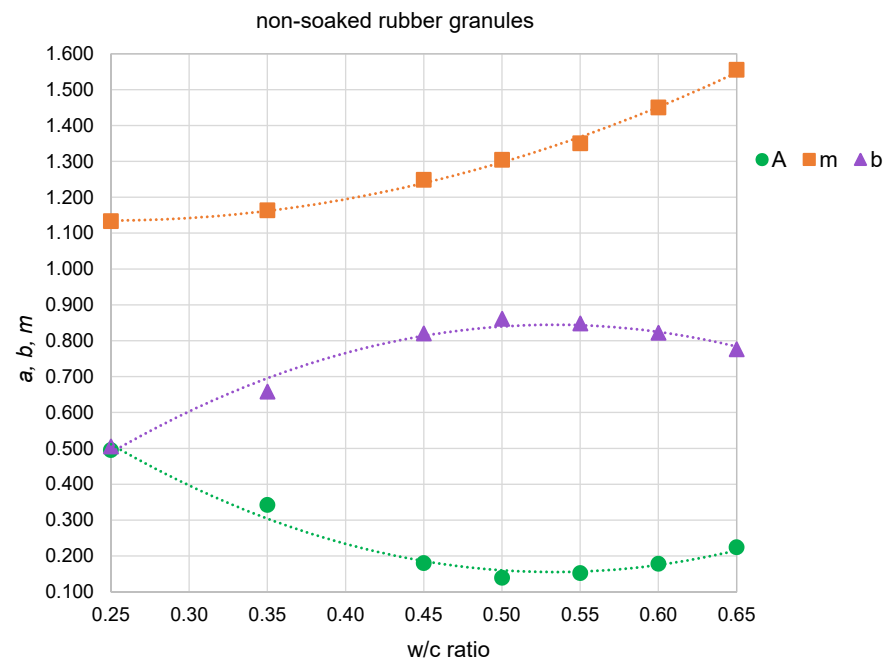

Figure 10. Calibration laws for the parameters $a, b$, and $m$, with non-soaked rubber particles included in the mixture.

\subsection{Validation of the Predicted Results}

The obtained mathematical laws were validated by comparing SRF values obtained from the GPR model predictions with the experimental results obtained by Eldin and Senouci [35] and Khatib and Bayomy [40], who used mix design proportions of the mixtures similar to those adopted in this study for model prediction. The results are presented in Table 3.

The final predicted SRF values are very close to those found by the authors in their experimental campaigns, thus confirming the validity of GPR model predictions and that the calibration laws obtained are suitable for mix design procedures of the rubbercrete mixtures. 
Table 3. Validation of calibration laws for the $\mathrm{w} / \mathrm{c}$ ratio and the SRF of the rubbercrete mixtures.

\begin{tabular}{|c|c|c|c|c|c|c|c|c|c|c|c|c|c|c|c|c|c|}
\hline Mixtures & $\begin{array}{l}\text { Cement } \\
\mathrm{kg} / \mathrm{m}^{3}\end{array}$ & $\begin{array}{l}\text { Sand } \\
\mathrm{kg} / \mathrm{m}^{3}\end{array}$ & $\begin{array}{l}\text { Gravel } \\
\mathrm{kg} / \mathrm{m}^{3}\end{array}$ & $\begin{array}{l}\text { Water } \\
\mathrm{kg} / \mathrm{m}^{3}\end{array}$ & $\begin{array}{c}\text { Pre- } \\
\text { Treatments } \\
\text { of } \\
\text { Rubber }\end{array}$ & $w / c$ & $\begin{array}{l}\text { Total Volume } \\
\text { of Aggregates } \\
/ \mathbf{m}^{3}\end{array}$ & $\begin{array}{c}\text { \% Fine } \\
\text { Aggregates } \\
\text { /Total Volume } \\
\text { of Aggregates }\end{array}$ & $\begin{array}{c}\text { \% Substitution } \\
\text { of Fine } \\
\text { Aggregates } \\
\text { (Referred to the } \\
\text { Volume of Fine } \\
\text { Aggregates) } \\
\end{array}$ & $\begin{array}{l}\text { Compressive } \\
\text { Strength } \\
\text { MPa }\end{array}$ & $\begin{array}{l}\text { SRF } \\
\text { (Experi- } \\
\text { mental) }\end{array}$ & $a$ & $b$ & $m$ & $\begin{array}{c}\text { SRF } \\
\text { (Polyno- } \\
\text { mial) }\end{array}$ & $k$ & $\begin{array}{c}\text { SRF } \\
\text { (Exponential) }\end{array}$ \\
\hline \multirow[t]{5}{*}{$\begin{array}{l}\text { Eldin and } \\
\text { Senouci [35] }\end{array}$} & 447 & 629 & 1116 & 214 & $\begin{array}{l}\text { Soaked in } \\
\text { water }\end{array}$ & 0.48 & 0.72 & 36.11 & 0 & 35 & 1.00 & 0.427 & 0.573 & 1.399 & $9 \quad 1.00$ & 0.009 & 1.00 \\
\hline & & & & & & & & & 25 & 23.4 & 0.67 & & & & 0.81 & & 0.80 \\
\hline & & & & & & & & & 50 & 19.2 & 0.55 & & & & 0.64 & & 0.64 \\
\hline & & & & & & & & & 75 & 14.7 & 0.42 & & & & 0.51 & & 0.51 \\
\hline & & & & & & & & & 100 & 12.4 & 0.35 & & & & 0.43 & & 0.41 \\
\hline \multirow[t]{9}{*}{$\begin{array}{l}\text { Khatib and } \\
\text { Bayomy [40] }\end{array}$} & 388 & 786 & 1024 & 186 & $\begin{array}{c}\text { non- } \\
\text { soaked }\end{array}$ & 0.48 & 0.68 & 42.65 & 0 & 37.5 & 1.00 & 0.168 & 0.832 & 1.273 & $\begin{array}{ll}3 & 1.00\end{array}$ & 0.017 & 1.00 \\
\hline & & & & & & & & & 5 & 35 & 0.93 & & & & 0.95 & & 0.92 \\
\hline & & & & & & & & & 10 & 30.5 & 0.81 & & & & 0.90 & & 0.85 \\
\hline & & & & & & & & & 15 & 29 & 0.77 & & & & 0.84 & & 0.78 \\
\hline & & & & & & & & & 20 & 25.7 & 0.69 & & & & 0.79 & & 0.72 \\
\hline & & & & & & & & & 40 & 18 & 0.48 & & & & 0.60 & & 0.51 \\
\hline & & & & & & & & & 60 & 9 & 0.24 & & & & 0.43 & & 0.37 \\
\hline & & & & & & & & & 80 & 4.8 & 0.13 & & & & 0.28 & & 0.26 \\
\hline & & & & & & & & & 100 & 3 & 0.08 & & & & 0.17 & & 0.19 \\
\hline
\end{tabular}




\section{Conclusions}

In this paper, a comprehensive study was performed on different mix design parameters that influence rubbercrete compressive strength: cement content $\left(\mathrm{v}_{1}\right)$, fine aggregate content $\left(\mathrm{v}_{2}\right)$, coarse aggregate content $\left(\mathrm{v}_{3}\right)$, aggregate pre-treatment condition $\left(\mathrm{v}_{4}\right)$ (one for soaked and zero for non-soaked), water-to-cement ratio $\left(\mathrm{v}_{5}\right)$, fine aggregate replacement percentage $\left(\mathrm{v}_{6}\right)$, and coarse aggregate replacement percentage $\left(\mathrm{v}_{7}\right)$. Advanced modelling techniques, i.e., SVM and GRP models, were employed to predict rubbercrete compressive strength behaviour. In this study data, we observed that the GPR model performed better compared to the SVM model. Simple equations were proposed to calculate the strength reduction factor. Calibration of the parameters of these equations was carried out considering the influence of the water/cement ratio. The accuracy of the developed equations and the predicted results was verified using experimental data in the literature. This study can aid in the study of rubbercrete and assist in promoting its usage among professionals without needing to perform preliminary experimental tests on the material.

Author Contributions: Conceptualization, A.G. and C.C.; methodology, A.G., C.C., and G.V.; software, G.V.; validation, C.C.; data curation, C.C.; writing-original draft preparation, C.C. and G.V.; writing-review and editing, C.C.; supervision, A.G. All authors have read and agreed to the published version of the manuscript.

Funding: This research received no external funding.

Data Availability Statement: The data presented in this study are available within the article.

Conflicts of Interest: The authors declare no conflict of interest. 


\section{Appendix A}

Table A1. Experimental data in the literature.

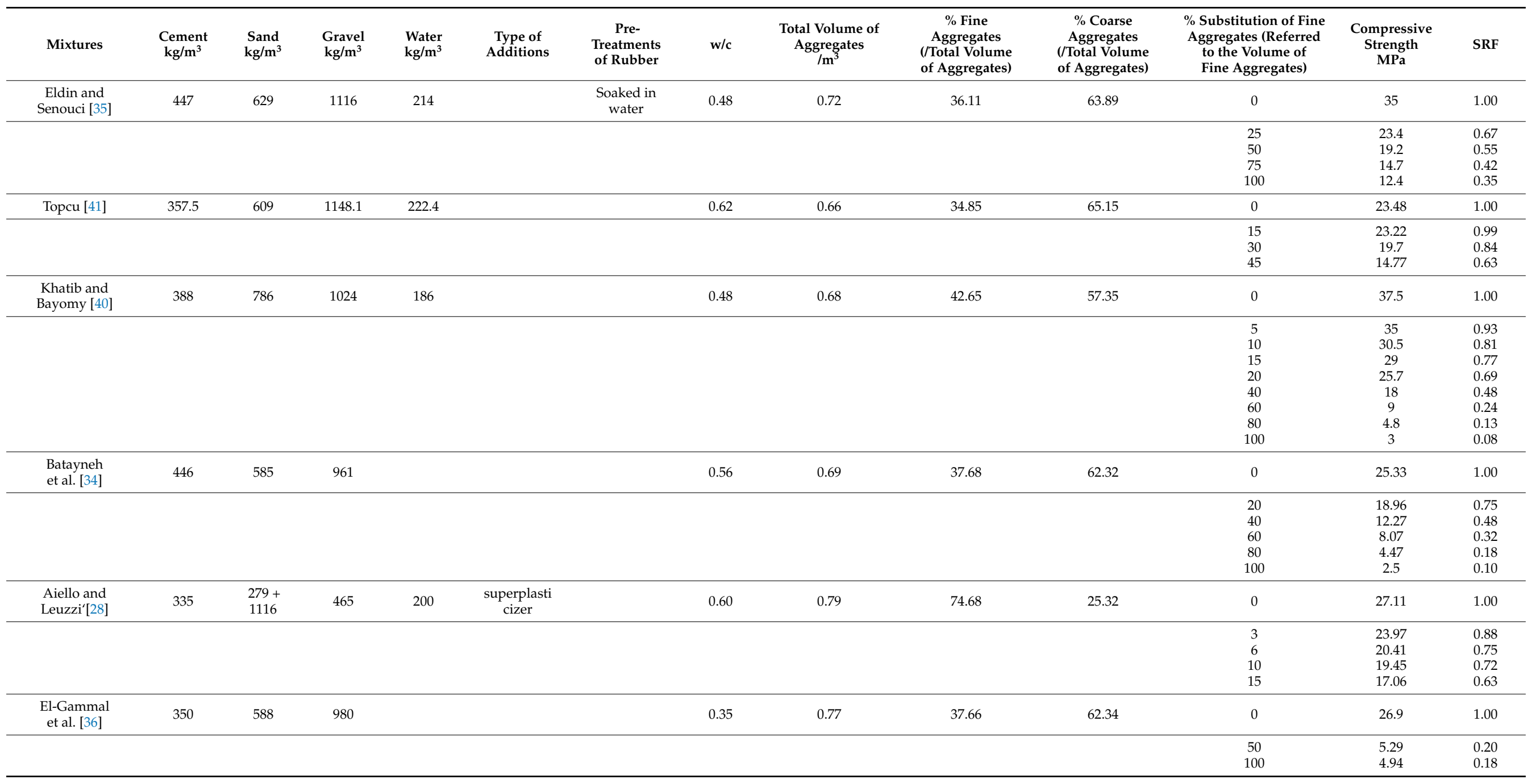


Table A1. Cont.

\begin{tabular}{|c|c|c|c|c|c|c|c|c|c|c|c|c|c|}
\hline Mixtures & $\begin{array}{l}\text { Cement } \\
\mathrm{kg} / \mathrm{m}^{3}\end{array}$ & $\begin{array}{l}\text { Sand } \\
\mathrm{kg} / \mathrm{m}^{3}\end{array}$ & $\begin{array}{l}\text { Gravel } \\
\mathrm{kg} / \mathrm{m}^{3}\end{array}$ & $\begin{array}{l}\text { Water } \\
\mathrm{kg} / \mathrm{m}^{3}\end{array}$ & $\begin{array}{c}\text { Type of } \\
\text { Additions }\end{array}$ & $\begin{array}{c}\text { Pre- } \\
\text { Treatments } \\
\text { of Rubber }\end{array}$ & $w / c$ & $\begin{array}{l}\text { Total Volume of } \\
\text { Aggregates } \\
/ \mathrm{m}^{3}\end{array}$ & $\begin{array}{c}\text { \% Fine } \\
\text { Aggregates } \\
\text { (/Total Volume } \\
\text { of Aggregates) }\end{array}$ & $\begin{array}{c}\text { \% Coarse } \\
\text { Aggregates } \\
\text { (/Total Volume } \\
\text { of Aggregates) }\end{array}$ & $\begin{array}{l}\text { \% Substitution of Fine } \\
\text { Aggregates (Referred } \\
\text { to the Volume of } \\
\text { Fine Aggregates) }\end{array}$ & $\begin{array}{l}\text { Compressive } \\
\text { Strength } \\
\text { MPa }\end{array}$ & SRF \\
\hline \multirow[t]{2}{*}{ Godfrey [38] } & 475 & 775 & 950 & & & $\begin{array}{l}\text { Soaked in } \\
\text { water }\end{array}$ & 0.38 & 0.73 & 44.52 & 55.48 & 0 & 58.39 & 1.00 \\
\hline & & & & & & & & & & & $\begin{array}{l}20 \\
40\end{array}$ & $\begin{array}{l}27.55 \\
16.13\end{array}$ & $\begin{array}{l}0.47 \\
0.28\end{array}$ \\
\hline Grinys et al. [39] & 451 & 875 & 949 & & $\begin{array}{c}\text { superplasti } \\
\text { cizer }\end{array}$ & & 0.35 & 0.75 & 48 & 52 & 0 & 64 & 1.00 \\
\hline \multirow[t]{2}{*}{$\begin{array}{l}\text { Tung-Chai } \\
\text { Ling [42] }\end{array}$} & 328 & 1246.4 & 590.4 & & $\begin{array}{c}\text { superplasti } \\
\text { cizer }\end{array}$ & & 0.45 & 0.82 & 56.7 & 43.3 & 0 & 31.1 & 1.00 \\
\hline & & & & & & & & & & & $\begin{array}{l}10 \\
20 \\
30\end{array}$ & $\begin{array}{l}42.5 \\
15.6 \\
11.7 \\
\end{array}$ & $\begin{array}{l}1.37 \\
0.50 \\
0.38 \\
\end{array}$ \\
\hline \multirow[t]{2}{*}{$\begin{array}{l}\text { Mohammed and } \\
\text { Azmi [32] }\end{array}$} & 556.1 & 803.58 & 697.32 & 228 & & & 0.41 & 0.66 & 53.03 & 46.97 & 0 & 35.5 & 1.00 \\
\hline & & & & & & & & & & & $\begin{array}{l}10 \\
15 \\
20 \\
30\end{array}$ & $\begin{array}{l}25.7 \\
21.2 \\
18.2 \\
14.3 \\
\end{array}$ & $\begin{array}{l}0.72 \\
0.60 \\
0.51 \\
0.40\end{array}$ \\
\hline \multirow[t]{2}{*}{$\begin{array}{l}\text { Mohammed and } \\
\text { Azmi [32] }\end{array}$} & 400 & 887.16 & 769.84 & 228 & & & 0.57 & 0.73 & 53.42 & 46.58 & 0 & 29.56 & 1.00 \\
\hline & & & & & & & & & & & $\begin{array}{l}10 \\
15 \\
20 \\
30\end{array}$ & $\begin{array}{c}20.21 \\
17.5 \\
14.5 \\
11.13 \\
\end{array}$ & $\begin{array}{l}0.68 \\
0.59 \\
0.49 \\
0.38\end{array}$ \\
\hline \multirow[t]{2}{*}{$\begin{array}{l}\text { Mohammed and } \\
\text { Azmi [32] }\end{array}$} & 335.29 & 921.8 & 799.9 & 228 & & & 0.68 & 0.75 & 53.33 & 46.67 & 0 & 23.4 & 1.00 \\
\hline & & & & & & & & & & & $\begin{array}{l}10 \\
15 \\
20 \\
30\end{array}$ & $\begin{array}{c}18.2 \\
15.6 \\
12.43 \\
10.5 \\
\end{array}$ & $\begin{array}{l}0.78 \\
0.67 \\
0.53 \\
0.45\end{array}$ \\
\hline \multirow[t]{2}{*}{$\begin{array}{l}\text { Mohammed and } \\
\text { Azmi [32] }\end{array}$} & 592.68 & 775.96 & 673.35 & 243 & & & 0.41 & 0.63 & 53.54 & 46.46 & 0 & 44.3 & 1.00 \\
\hline & & & & & & & & & & & $\begin{array}{l}10 \\
15 \\
20 \\
30\end{array}$ & $\begin{array}{l}34.21 \\
24.56 \\
22.19 \\
18.56\end{array}$ & $\begin{array}{l}0.77 \\
0.55 \\
0.50 \\
0.42\end{array}$ \\
\hline
\end{tabular}


Table A1. Cont.

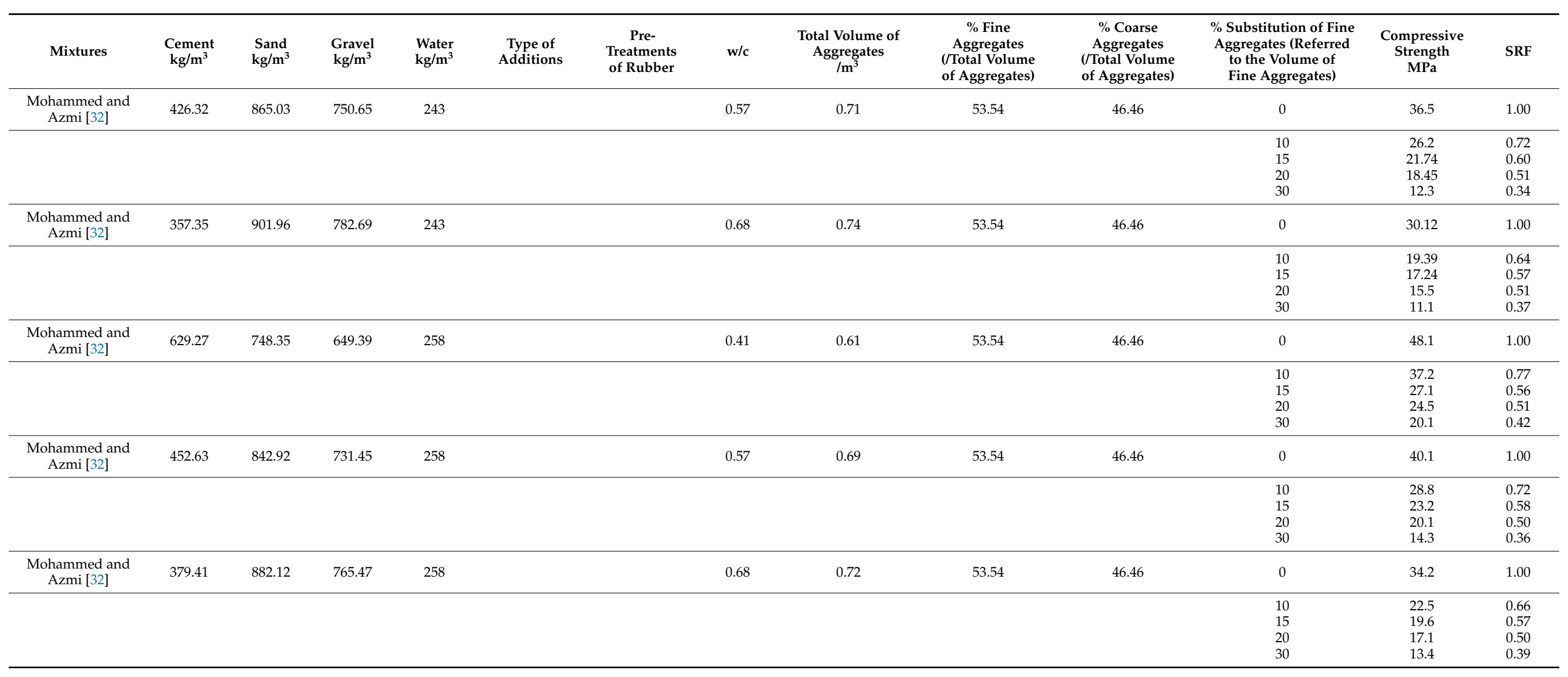




\section{References}

1. Thomas, B.S.; Gupta, R.C.; Panicker, V.J. Recycling of waste tire rubber as aggregate in concrete: Durability-related performance. J. Clean. Prod. 2016, 112, 504-513. [CrossRef]

2. Mohammed, B.S.; Anwar Hossain, K.M.; Eng Swee, J.T.; Wong, G.; Abdullahi, M. Properties of crumb rubber hollow concrete block. J. Clean. Prod. 2012, 23, 57-67. [CrossRef]

3. Benazzouk, A.; Douzane, O.; Mezreb, K.; Quéneudec, M. Physico-mechanical properties of aerated cement composites containing shredded rubber waste. Cem. Concr. Compos. 2006, 28, 650-657. [CrossRef]

4. Colom, X.; Cañavate, J.; Carrillo, F.; Velasco, J.I.; Pagès, P.; Mujal, R.; Nogués, F. Structural and mechanical studies on modified reused tyres composites. Eur. Polym. J. 2006, 42, 2369-2378. [CrossRef]

5. Hernández-Olivares, F.; Barluenga, G.; Bollati, M.; Witoszek, B. Static and dynamic behaviour of recycled tyre rubber-filled concrete. Cem. Concr. Res. 2002, 32, 1587-1596. [CrossRef]

6. Lee, B.I.; Burnett, L.; Miller, T.; Postage, B.; Cuneo, J. Tyre rubber/cement matrix composites. J. Mater. Sci. Lett. 1993, 12, 967-968. [CrossRef]

7. Rostami, H.; Lepore, J.; Silverstraim, T.; Zundi, I. Use of recycled rubber tires in concrete. In Proceedings of the International Conference: Concrete 2000: Economic and Durable Construction through Excellence, Dundee, UK, 7-9 September 1993; pp. 391-399.

8. Segre, N.; Joekes, I. Use of tire rubber particles as addition to cement paste. Cem. Concr. Res. 2000, 30, 1421-1425. [CrossRef]

9. Skripkiunas, G.; Grinys, A.; Černius, B. Deformation properties of concrete with rubber waste additives. Mater. Sci. 2007, 13, 219-223.

10. Skripkiunas, G.; Grinys, A.; Daukšys, M. Using tires rubber waste for modification of concrete properties. In Proceedings of the Sustainable Construction Materials and Technologies International Conference, Coventry, UK, 11 June 2007; pp. 85-90.

11. De Brito, J.; Saikia, N. Recycled Aggregate in Concrete: Use of Industrial, Construction and Demolition Waste; Springer Science \& Business Media: Berlin/Heidelberg, Germany, 2012.

12. Demir, F.; Yesilata, B.; Turgut, P.; Bulut, H.; Isiker, Y. Investigation of the effects of pH, aging and scrap tire content on the dissolution behaviors of new scrap tire-concrete mixture structures. J. Clean. Prod. 2015, 93, 38-46. [CrossRef]

13. Shu, X.; Huang, B. Recycling of waste tire rubber in asphalt and portland cement concrete: An overview. Constr. Build. Mater. 2014, 67, 217-224. [CrossRef]

14. Mohammed, B.S.; Azmi, N.J.; Abdullahi, M. Evaluation of rubbercrete based on ultrasonic pulse velocity and rebound hammer tests. Constr. Build. Mater. 2011, 25, 1388-1397. [CrossRef]

15. Mohammed, B.S. Structural behavior and $\mathrm{m}-\mathrm{k}$ value of composite slab utilizing concrete containing crumb rubber. Constr. Build. Mater. 2010, 24, 1214-1221. [CrossRef]

16. Ganjian, E.; Khorami, M.; Maghsoudi, A.A. Scrap-tyre-rubber replacement for aggregate and filler in concrete. Constr. Build. Mater. 2009, 23, 1828-1836. [CrossRef]

17. Bravo, M.; De Brito, J. Concrete made with used tyre aggregate: Durability-related performance. J. Clean. Prod. 2012, 25, 42-50. [CrossRef]

18. Li, G.; Stubblefield, M.A.; Garrick, G.; Eggers, J.; Abadie, C.; Huang, B. Development of waste tire modified concrete. Cem. Concr. Res. 2004, 34, 2283-2289. [CrossRef]

19. Onuaguluchi, O.; Panesar, D.K. Hardened properties of concrete mixtures containing pre-coated crumb rubber and silica fume. J. Clean. Prod. 2014, 82, 125-131. [CrossRef]

20. Youssf, O.; ElGawady, M.A.; Mills, J.E. Static cyclic behaviour of FRP-confined crumb rubber concrete columns. Eng. Struct. 2016, 113, 371-387. [CrossRef]

21. Valadares, F.; Bravo, M.; De Brito, J. Concrete with used tire rubber aggregates: Mechanical performance. ACI Mater. J. 2012, 109, 283-292.

22. Topçu, I.B.; Demir, A. Durability of rubberized mortar and concrete. J. Mater. Civ. Eng. 2007, 19, 173-178. [CrossRef]

23. Turatsinze, A.; Garros, M. On the modulus of elasticity and strain capacity of Self-Compacting Concrete incorporating rubber aggregates. Resour. Conserv. Recycl. 2008, 52, 1209-1215. [CrossRef]

24. Eldin, N.N.; Senouci, A.B. Measurement and prediction of the strength of rubberized concrete. Cem. Concr. Compos. 1994, 16, 287-298. [CrossRef]

25. Topçu, I.B.; Avcular, N. Collision behaviours of rubberized concrete. Cem. Concr. Res. 1997, 27, 1893-1898. [CrossRef]

26. Topçu, İ.B.; Sarıdemir, M. Prediction of rubberized concrete properties using artificial neural network and fuzzy logic. Constr. Build. Mater. 2008, 22, 532-540. [CrossRef]

27. Gregori, A.; Castoro, C.; Marano, G.C.; Greco, R. Strength reduction factor of concrete with recycled rubber aggregates from tires. J. Mater. Civ. Eng. 2019, 31, 04019146. [CrossRef]

28. Aiello, M.A.; Leuzzi, F. Waste tyre rubberized concrete: Properties at fresh and hardened state. Waste Manag. 2010, 30, 1696-1704. [CrossRef] [PubMed]

29. Albano, C.; Camacho, N.; Reyes, J.; Feliu, J.L.; Hernández, M. Influence of scrap rubber addition to Portland I concrete composites: Destructive and non-destructive testing. Compos. Struct. 2005, 71, 439-446. [CrossRef] 
30. Güneyisi, E.; Gesoğlu, M.; Özturan, T. Properties of rubberized concretes containing silica fume. Cem. Concr. Res. 2004, 34, 2309-2317. [CrossRef]

31. Papakonstantinou, C.G.; Tobolski, M.J. Use of waste tire steel beads in Portland cement concrete. Cem. Concr. Res. 2006, 36, 1686-1691. [CrossRef]

32. Mohammed, B.S.; Azmi, N.J. Strength reduction factors for structural rubbercrete. Front. Struct. Civ. Eng. 2014, 8, 270-281. [CrossRef]

33. Reda Taha, M.M.; El-Dieb, A.S.; Abd El-Wahab, M.A.; Abdel-Hameed, M.E. Mechanical, Fracture, and Microstructural Investigations of Rubber Concrete. J. Mater. Civ. Eng. 2008, 20, 640-649. [CrossRef]

34. Batayneh, M.K.; Marie, I.; Asi, I. Promoting the use of crumb rubber concrete in developing countries. Waste Manag. 2008, 28, 2171-2176. [CrossRef]

35. Eldin, N.N.; Senouci, A.B. Rubber-Tire Particles as Concrete Aggregate. J. Mater. Civ. Eng. 1993, 5, 478-496. [CrossRef]

36. El-Gammal, A.; Abdel-Gawad, A.K.; El-Sherbini, Y.; Shalaby, A. Compressive strength of concrete utilizing waste tire rubber. J. Emerg. Trends Eng. Appl. Sci. 2010, 1, 96-99.

37. De Béjar, L.A.; Rushing, T.S. Relative compression strength evolution of silica-fume ultrahigh-performance concrete under saturated adiabatic hydration using virtual tests. J. Mater. Civ. Eng. 2018, 30, 04017260. [CrossRef]

38. Godfrey, T. Mechanical Properties of Rubberised Concrete; University of Loughborough: Loughborough, UK, 2012.

39. Grinys, A.; Sivilevičius, H.; Daukšys, M. Tyre rubber additive effect on concrete mixture strength. J. Civ. Eng. Manag. 2012, 18, 393-401. [CrossRef]

40. Khatib, Z.K.; Bayomy, F.M. Rubberized Portland Cement Concrete. J. Mater. Civ. Eng. 1999, 11, 206-213. [CrossRef]

41. Topçu, I.B. The properties of rubberized concretes. Cem. Concr. Res. 1995, 25, 304-310. [CrossRef]

42. Ling, T.-C. Effects of compaction method and rubber content on the properties of concrete paving blocks. Constr. Build. Mater. 2012, 28, 164-175. [CrossRef]

43. Sain, S.R.; Vapnik, V.N. The Nature of Statistical Learning Theory. Technometrics 1996, 38, 409. [CrossRef]

44. Meyer, D. Support vector machines. R News 2001, 1, 23-26.

45. Hearst, M.; Dumais, S.; Osuna, E.; Platt, J.; Scholkopf, B. Support vector machines. IEEE Intell. Syst. Their. Appl. 1998, 13, 18-28. [CrossRef]

46. Gershman, S.J.; Blei, D.M. A tutorial on Bayesian nonparametric models. J. Math. Psychol. 2012, 56, 1-12. [CrossRef]

47. Williams, C.K.I. Prediction with Gaussian Processes: From Linear Regression to Linear Prediction and Beyond. In Learning in Graphical Models; MIT Press: Cambridge, MA, USA, 1998; pp. 599-621.

48. Rasmussen, C.E.; Williams, C.K.I. Gaussian Processes for Machine Learning; Dietterich, T., Ed.; MIT Press: Cambridge, MA, USA, 2006; Volume 14, ISBN 978-0-262-18253-9.

49. Huang, W.; Huang, X.; Xing, Q.; Zhou, Z. Strength reduction factor of crumb rubber as fine aggregate replacement in concrete. J. Build. Eng. 2020, 32, 101346. [CrossRef]

50. Gregori, A.; Castoro, C.; Mercuri, M.; Angiolilli, M. Modeling the Mechanical Response of Rubberised Concrete. In Developments and Novel Approaches in Biomechanics and Metamaterials. Advanced Structured Materials; Abali, B., Giorgio, I., Eds.; Springer: Cham, Switzerland, 2020; Volume 132, pp. 341-352. [CrossRef]

51. Gregori, A.; Castoro, C.; Mercuri, M.; Angiolilli, M. Numerical modelling of the mechanical behaviour of rubbercrete. Comput. Struct. 2021, 242, 106393. [CrossRef]

52. Ahmad, H.S.; Abendeh, R.M.; Hunaiti, Y.M. Evaluation of concrete-steel interfaces in steel tubes filled with chipped rubberconcrete. Proc. Inst. Civ. Eng. Struct. Build. 2020, 1-23. [CrossRef] 